\title{
Research on the International Exchange and Cooperation of Universities against the Background of the Belt and Road Initiative
}

\author{
Wang XI \\ International Exchange and Cooperation Department, Tianjin University of Finance and Economics, \\ Tianjin, China \\ Email:345178910@qq.com
}

Keywords: The Belt and Road Initiative, Colleges and universities international, Exchanges and cooperation.

\begin{abstract}
The Belt and Road Initiative is an important manifestation of China's further opening up to the outside world, which is conducive to the countries' better development along the land and sea Silk Roads. In the process of promoting this initiative, China's exchanges and cooperation with countries along the route have become increasingly frequent. For universities, the implementation of the Belt and Road Initiative has offered them opportunities to strengthen international exchange and cooperation. This paper aims to make a related analysis on the issues of international exchange and cooperation in colleges and universities in the context of the Belt and Road Initiative.
\end{abstract}

\section{Introduction}

The Belt and Road Initiative is a strategic decision for China's economy which has entered a new normal, and the implementation of this initiative has provided a broad platform for the development of China as well as the countries along the routes. With more and more countries participating in the construction of the Belt and Road Initiative, international exchanges and cooperation in universities is also becoming increasingly frequent. Under this circumstance, this strategy will surely push forward the international exchanges and cooperation in universities, accelerate the sharing of education resources and then in return, serve this initiative in a better way, promoting economic growth.

Therefore, colleges and universities should fully recognize and size this opportunity to actively devote themselves to international exchange and cooperation so as to constantly improve their international power.

\section{Introduction of the Belt and Road Initiative}

The Belt and Road Initiative, which refers to the Silk Road Economic Belt and the 21st Century Maritime Silk Road, was proposed by the President Xi Jinping in September and October 2013 respectively with the purpose of improving China's economic strength.

The implementation will fully rely on the existing bilateral and multilateral mechanisms of China and relevant countries to carry out regional cooperation through effective platforms. For China, it is an important embodiment of deepening opening up to overseas and further breaking the closed pattern. For those countries along the routes, it is of great significance to promote their common development by carrying out cooperation and exchanges among countries and providing a great opportunity for them [1].

\section{The Main Problems Existing in International Exchange and Cooperation in Universities}

International exchanges and cooperation in colleges and universities refer to the activities held by universities or educational institutions of those countries alongside aiming to achieve common education goals and interests. Playing an active role in cultivating professional talents and promoting this initiative, exchanges and cooperation in universities have become an inevitable trendin the context of the Belt and Road Initiative. However, there are also many problems which 
have emerged as a result of transnational exchanges and cooperation.

\section{Relatively Weak International Competitiveness of China's Universities}

As far as the regions along the routes are concerned, the developed countries in the east clearly outperform China in economic, cultural, educational, and scientific and technological areas. In the whole, our universities lack strategic thinking and macro design as well as practical experience in education, leading to a lower position in the process of exchanges and cooperation.

\section{Insufficient Teaching Staff and Material Construction}

As far as the colleges and universities of China are concerned, which are in the area along the routes, many of them do not have bilingual textbooks and lack international teachers. Compared with conventional teaching, bilingual teaching requires a lot of time and efforts, and the requirements for professional teacher are also relatively high. The lack of professional teachers and teaching materials has led to the slow pace of international exchange and cooperation in colleges and universities to some extent.

\section{Single Mode of International Exchange and Cooperation}

Although the Belt and Road Initiative has provided great convenience for international exchanges and cooperation among colleges and universities, it cannot be ignored that the current model of international exchange and cooperation in colleges and universities is still relatively simple. Most colleges and universities focus on sending students abroad to study, providing internship programs, conducting overseas training for teachers, and recruiting foreign students. It can be said that such international exchanges and cooperation are relatively simple and not deep enough.

\section{New Opportunities Brought by Belt and Road Initiative for International Exchanges and Cooperation among Universities}

\section{An Increasing Number of Partners}

Including China, a total of 66 countries along the route have been involved. With the deepening implementation, more and more countries are participating. This strategy will effectively play a role in connecting these countries and attracting more partners in more fields to exchange and cooperate within universities, thus breaking new ground for these universities.

\section{More Varied Modes of Exchange and Cooperation}

Aiming at promoting common development and common prosperity, the Belt and Road Initiative is speeding up exchanges and cooperation among countries with its advancement. In this process, frequent exchanges will inevitably lead to an increase in the demand for talents and new partnership needs. At a result, complex and diverse patterns will dominant the main position instead of the traditional single-mode cooperation, which is conducive to the efficiency of educational resources [2].

\section{Higher Quality of University Education}

Enjoying the benefits of this initiative, educational resources have been further shared not only in China, but also abroad. In China, universities along the route have been limited by teaching resources for a long time, leading to poor quality of education. Fortunately, the implementation of this initiative has brought in more international exchanges and cooperation as well as talents with an international background for universities. These changes will witness a major progress in the quality of education in universities[3]. 


\section{Strategies for International Exchange and Cooperation in Colleges and Universities Establishing a “Going Global” Strategy}

As far as the current situation is concerned, colleges and universities along the Belt and Road Initiative in China are less competitive in international competition which is determined by multiple factors. To reverse this unfavorable situation and strengthen its influence, it is necessary for them to put the "Going Global” plan into effect. Only by actively going out, colleges and universities could recognize the deficiencies and then improve themselves in a targeted manner. Besides, colleges and universities along the route should actively cooperate with universities in the eastern region and learn from their experiences so as to continuously improve their own teaching capacity. In the meantime, by enhancing cooperation with the universities along the Belt and Road Initiative, they should pay attention to the introduction of advanced educational resources and then their comprehensive ability [4].

\section{Internationalizing Curriculums}

With the implementation of the Belt and Road Initiative, China's frequent exchanges with other countries alongside are calling for the importance of international talents. Based on this talent demand, the internationalization of college curriculum is very necessary. When setting up courses in colleges and universities, we must do a good job of classifying courses and plan different international development goals according to the different courses. At the same time, we must firmly follow the trend of international exchanges and cooperation and speed up the construction of national textbooks, especially bilingual textbooks. They are all of major importance in cultivating professional and practical talents and speeding up the development of the Belt and Road Initiative[5].

\section{Strengthening the Construction of an International Teaching Stuff}

To fully realize international exchanges and cooperation in colleges and universities under the Belt and Road Initiative background, higher requirements on the quality of teachers are put forward. Teachers are required not only to be professional but also to have a good master of foreign languages. Based on the needs of strategic development, colleges and universities are duty-bound to establish an international team of teachers. The work comprises two parts: first, select outstanding teachers and send them abroad for further study by more foreign exchanges, such as visits and research; second, introduce more teachers who are professional and equipped with international education experience, so as to better international exchanges and cooperation [6]. In addition, they are required to establish training bases for overseas teachers and cultivate professional teaching staffs for a stronger competitiveness in the international exchanges and cooperation among universities.

\section{Optimizing the Existing Education Evaluation System}

With the advancement of the Belt and Road Initiative, the demands for international talents are climbing up, answering to the need of social development. Therefore, in the process of international exchanges and cooperation, universities should pay much attention to education evaluation, making the goal of personnel training always in line with the human resources standards of the international labor market, and continue to optimize teaching philosophy through effective education evaluation so as to cultivate more specialized talents.

\section{Conclusion}

In summary, the implementation of the Belt and Road Initiative has provided a good opportunity for universities to promote international exchanges and cooperation. Linking the countries along the route, the initiative makes it possible for them to better interact with each other and promote mutual development. To take better advantage of this strategy, colleges and universities should actively accelerate the curriculum reform, implement the "Going Global” plan, increase the training of 
professional teachers, and improve education evaluation methods to promote national education and cooperation, sharing a brighter prospect.

\section{References}

[1] Na Min. Problems and Strategies of International Exchanges and Cooperation in Higher Vocational Colleges Under the Background of the Belt and Road Initiative - Taking Yunnan Institute of Mechanical and Electrical Technology as an Example [J]. Western Quality Education, 2017, 3(06): 129.

[2] Yutao Li. An Analysis of International Exchanges and Cooperation in Engineering Colleges Based on the Belt and Road Initiative[J]. Curriculum Education Research, 2017(12):3-4.

[3] Lu Qi. The Construction of International Cooperation and Exchange System in Universities[J]. Curriculum Education Research, 2016(17): 15-16.

[4] Wei Yang. Some Thoughts on Deepening the International Exchange and Cooperation of Universities in the New Era[J]. Chinese Market, 2015(32): 252-255.

[5] Jing Jiang, Dongchang Shang, Defan Zhang, Dezhong Wang. Research on the Strategies of International Exchange and Cooperation in Local Universities[J]. Border Economy and Culture, 2015(07):83-84.

[6] Peng Li, Chengjia Liu. Understanding of the Issues of International Exchange and Cooperation in Chinese Universities [J]. China Power Education, 2012(26):10-11. 